\title{
STOCK MARKETS IN THE NEW ECONOMY
}

\author{
by
}

Boyan Jovanovic and Peter L. Rousseau

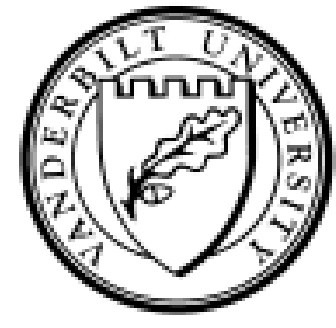

Working Paper No. 01-W18

August 2001

DEPARTMENT OF ECONOMICS

VANDERBILT UNIVERSITY

NASHVILLE, TN 37235

www.vanderbilt.edu/econ 


\title{
Stock Markets in the New Economy
}

\author{
Boyan Jovanovic and Peter L. Rousseau*
}

August 14, 2001

\section{Introduction}

The term "new economy" has, more than anything, come to mean a technological transformation, and in particular its embodiment in the computer and the internet. These technologies are more human capital intensive than earlier ones and have probably hastened the pace of the shift in the U.S. economy towards the service industries. The new economy is also commonly associated with economic "globalization" as reflected in the expansion of trade and the integration of capital markets, but this can be viewed as much as a symptom of technological change as an independent phenomenon.

Upon reflection, however, it is clear that the new economy is not entirely "new." There have always been new technologies, and each has, on the whole, demanded new skills. Technologies that have driven "new" economies of the past include steam, electricity, the internal combustion engine, antibiotics, and chemicals, and these were in turn refined in a host of smaller innovations. Here we will draw upon this rich past to see what today's new economy may hold in store.

The evidence shows quite clearly that we are in the midst of a major episode of Schumpeterian-style creative destruction, something like the electrification episode 100 years ago that David (1991) describes. Moreover, far more than electricity, we believe that information technology or "IT" represents an "invention in the method of inventing," as Griliches (1957 p. 502) put it when describing the advent of hybridization. This means that we will probably see a wave of new products, new firms, and faster productivity growth worldwide than we saw during the 20th century.

\footnotetext{
${ }^{*}$ Forthcoming in C. Bai and C. Yuen, eds., Technology and the New Economy, MIT Press, 2002. Boyan Jovanovic is professor of economics at the University of Chicago and New York University, a research associate of the National Bureau of Economic Research (NBER), and a consultant to the Federal Reserve Bank of Chicago. Peter L. Rousseau is assistant professor of economics at Vanderbilt University and a faculty research fellow of the NBER. The authors thank the NSF for financial help.
} 


\section{Technology and today's giants}

The flagship technologies of the most recent wave, the computer and internet, were brought into the market primarily by small and young firms. This suggests that the story of the IT revolution is for the most part one of entrants. Can the same be said for the great technologies of the past, such as electricity? A full technological history of entering firms over the past century is beyond the scope of our investigation, but a look at the technologies that today's giants brought into the market when they first listed on an organized stock exchange can nevertheless shed light on the question.

Table 1 lists the first product or process innovation for some well-known companies, along with their dates of founding, incorporation, and stock exchange listing. It also includes the share of total market capitalization that can be attributed to each firm's common stock at the end of 2000. The information is based upon our reading of individual company histories and an extension of the stock files distributed by University of Chicago's Center for Research in Securities Prices (CRSP) from its 1925 starting date back through $1885 .{ }^{1}$ The firms appearing in the table separate into roughly 3 groups: those based upon electricity and internal combustion, those based upon the chemicals and pharmaceuticals, and those based upon the computer and internet. Let us consider a few of the entries more closely:

- Electricity/Internal Combustion Engine: Two of largest companies in the United States today are General Electric (GE) and AT\&T. Founded in 1878, GE now accounts for 3.1 percent of total stock market value, and had already established a share of over 2 percent by 1910. AT\&T, founded in 1885, contributed 4.6 percent to total market value by 1928 , and more than 8.5 percent at the time of its forced breakup in 1984. Both were early entrants of the electricity era. GE came to life with the invention of the incandescent light bulb by Thomas Edison in 1880, while AT\&T established a long-distance telephone line from New York to Chicago in 1892 to make use of Bell's 1876 invention of the telephone. Both technologies represented quantum leaps in the modernization of industry and communications, and would come to improve greatly the quality of household life. Both firms listed on the NYSE about 15 years after founding. General Motors (GM) was an early entrant to the automobile industry, listing on the New York Stock Exchange (NYSE) in 1917 - nine years after its founding. By 1931 it accounted for more than 4 percent of stock market value, and its share

\footnotetext{
${ }^{1}$ We extended the CRSP stock files backward from their 1925 starting year by collecting year-end observations from 1885 to 1925 for all common stocks traded on the NYSE. Prices and par values are from the The Commercial and Financial Chronicle, which is also the source of firm-level data for the price indexes reported in the Cowles Commission's Common Stock Prices Indexes (1938). We obtained firm book capitalizations from Bradstreet's, The New York Times, and The Annalist. The resulting dataset includes 21,516 firms, and is described in detail in Jovanovic and Rousseau (2001a). The companies included in the Table 1 were chosen because they were large and well-known, and, not least, because the information we sought on them was available.
} 
Table 1

Key Dates in Selected Company Histories

\begin{tabular}{|c|c|c|c|c|c|}
\hline Company name & $\begin{array}{c}\text { Founding } \\
\text { date }\end{array}$ & $\begin{array}{l}1 \text { st major } \\
\text { product or } \\
\text { process } \\
\text { innovation }\end{array}$ & $\begin{array}{c}\text { Incorporation } \\
\text { date }\end{array}$ & $\begin{array}{c}\text { Listing } \\
\text { date }\end{array}$ & $\begin{array}{c}\% \text { of Stock } \\
\text { Market in } \\
2000\end{array}$ \\
\hline General Electric & 1878 & 1880 & 1892 & 1892 & 3.10 \\
\hline $\mathrm{A} \mathrm{T} \& \mathrm{~T}$ & 1885 & 1892 & 1885 & 1901 & 0.42 \\
\hline Detroit Edison & 1886 & 1904 & 1903 & 1909 & 0.04 \\
\hline General Motors & 1908 & 1912 & 1908 & 1917 & 0.19 \\
\hline Coca Cola & 1886 & 1893 & 1919 & 1919 & 0.99 \\
\hline Pacific Gas \& Electic & 1879 & 1879 & 1905 & 1919 & 0.05 \\
\hline Burroughs/Unisys & 1886 & 1886 & 1886 & 1924 & 0.03 \\
\hline Caterpillar & 1869 & 1904 & 1925 & 1929 & 0.11 \\
\hline Kimberly-Clark & 1872 & 1914 & 1880 & 1929 & 0.25 \\
\hline Procter \& Gamble & 1837 & 1879 & 1890 & 1929 & 0.67 \\
\hline Bristol-Myers Squibb & 1887 & 1903 & 1887 & 1933 & 0.94 \\
\hline Boeing & 1916 & 1917 & 1916 & 1934 & 0.38 \\
\hline Pfizer & 1849 & 1944 & 1900 & 1944 & 1.90 \\
\hline Merck & 1891 & 1944 & 1934 & 1946 & 1.41 \\
\hline Disney & 1923 & 1929 & 1940 & 1957 & 0.39 \\
\hline Hewlett Packard & 1938 & 1938 & 1947 & 1961 & 0.41 \\
\hline Time Warner & 1922 & 1942 & 1922 & 1964 & 0.41 \\
\hline McDonalds & 1948 & 1955 & 1965 & 1966 & 0.29 \\
\hline Intel & 1968 & 1971 & 1969 & 1972 & 1.32 \\
\hline Compaq & 1982 & 1982 & 1982 & 1983 & 0.17 \\
\hline Micron & 1978 & 1982 & 1978 & 1984 & 0.13 \\
\hline Microsoft & 1975 & 1980 & 1981 & 1986 & 1.51 \\
\hline America Online & 1985 & 1988 & 1985 & 1992 & 0.53 \\
\hline Amazon & 1994 & 1995 & 1994 & 1997 & 0.04 \\
\hline E-Bay & 1995 & 1995 & 1996 & 1998 & 0.06 \\
\hline
\end{tabular}

Data from Hoover's Online, Kelley (1954), and company websites.

The first major products or innovations for the firms listed in the table are: GE 1880, Edison patents incandescent light bulb; AT\&T 1892, completes phone line from New York to Chicago; DTE 1904, increases Detroit's electric capacity six-fold with new facilities; GM 1912, electric self-starter; Coca Cola 1893, patents soft-drink formula; PG\&E 1879, first electric utility; Burroughs/Unisys 1886, first adding machine; CAT 1904, gas driven tractor; Kimberly-Clark 1914, celu-cotton, a cotton substitute used in WWI; P\&G 1879, Ivory soap; Bristol-Myers Squibb 1903, Sal Hepatica, a laxative mineral salt; Boeing 1917, designs Model C seaplane; Pfizer 1944, deep tank fermentation to mass produce penicillin; Merck 1944, cortisone (first steroid); Disney 1929, cartoon with soundtrack; HP 1938, audio oscillator; Time-Warner 1942, "Casablanca"; McDonalds 1955, fast food franchising begins; Intel 1971, 4004 microprocessor (8088 microprocessor in 1978); Microsoft 1980, develops DOS; Compaq 1982, portable IBM-compatible computer; Micron 1982, computer "eye" camera; AOL 1988, "PC-Link"; Amazon 1995, first online bookstore; E-Bay 1995, first online auction house. 
would hover between 4 and 6.5 percent until 1965, when it began to decline gradually to its current share of only 0.2 percent. These examples suggest that many of the leading entrants of the turn of the 20th century created lasting market value. Further, the ideas that sparked their emergence were brought to market relatively quickly.

- Chemicals/Pharmaceuticals: Procter and Gamble, Bristol-Myers-Squibb, and Pfizer are now all leaders in their respective industries, but took much longer to list on the NYSE than the electrification-era firms. In fact, both Pfizer and P\&G were established before 1850, and thus predate all of them. Despite P\&G's early start and creation of the Ivory soap brand in 1879, it was not until 1932 that the company took its place among the largest U.S. firms by exploiting advances in radio transmission to sponsor the first "soap opera." Pfizer's defining moment came when it developed a process for mass-producing the breakthrough drug penicillin during the Second World War, and the good reputation that the firm earned at that time later helped it to became the main producer of the Salk and Sabin polio vaccines. In Pfizer's case, like that of P\&G, the company's management and culture had been in place for some time when a new technology (in Pfizer's case antibiotics) presented a great opportunity.

- Computer/IT: Firms at the core of the recent IT revolution, such as Intel, Microsoft, and Amazon, came to market shortly after founding. Intel listed in 1972, only four years after starting up, and now accounts for 1.3 percent of total stock market value. Microsoft took eleven years to go public. Conceived in an Albuquerque hotel room by Bill Gates in 1975, the company, with its new disk operating system (MS-DOS), was perhaps ahead of its time, but later joined the ranks of today's corporate giants with the proliferation of the personal computer. In 1998, Microsoft accounted for more than 2.5 percent of the stock market, but this share fell to 1.5 percent over the next two years in the midst of antitrust action. Amazon caught the internet wave from the outset to become the world's first on-line bookstore, going public in 1997 - only three years after its founding. As the complexities of integrating goods distribution with an internet front-end came into sharper focus over the ensuing years, however, and as competition among internet retailers continued to grow, Amazon's market capitalization by 2001 had been cut in half to less than 0.1 percent of total stock market value.

These firms, as well as the others listed in Table 1, brought new technologies into the stock market and accounted for nearly 16 percent of its value at the close of 2000 . The firms themselves also seem to have entered the stock market sooner during the electricity and computer/internet revolutions, at opposite ends of the 20th century, than firms based on mid-century technologies. In the next two sections, we examine these observations more systematically in a universe that includes all exchange-listed firms. 


\section{How much value do these technological vintages command today?}

The examples in the final column of Table 1 suggest that firms entering the stock market with a new technology seem to create lasting value. Is this just a characteristic of today's largest companies, or does it apply more generally? One measure of the importance of a past technology is how long the firms that carried it to market have survived, and how much value they have created. Jovanovic and Rousseau (2001a) show that a firm's organizational imprint, which in their model is created upon entry to the stock market, is shaped largely by the available technologies, and that the quality of this imprint relates closely to market value even today. The solid line in Figure 1 provides an accounting of the value in 1998 of all firms that were then listed on the three major U.S. stock exchanges, i.e. the NYSE, the American Stock Exchange (AMEX), and NASDAQ, by year of listing, and offers strong evidence in favor of this view. ${ }^{2}$

The leading vintages in the figure retain a strong presence in 1998 even per unit of investment. The dashed line accounts for all cumulative real investment by the year of that investment. ${ }^{3}$ Relative to investment, the '50s and even the '60s, which saw the Dow and the S\&P 500 indexes do very well and which some economists refer to as a golden age - did not create as much lasting value as the '20s.

In a one-sector world in which every firm financed its start-up investment with a stock issue and then simply kept up its capital and paid for all parts and maintenance out of its profits, each firm's current value would be proportional to its initial investment, and the dashed lines and the solid lines would coincide. Why, then, does the solid line deviate from the dashed line? Why, for example, do the vintage-'20s firms account for relatively more stock-market value than they do for gross investment? Several explanations come to mind:

1. Technology: The entrants of the 20's came in with technologies and products that were better and therefore either $(a)$ accounted for a bigger-than-average

\footnotetext{
${ }^{2}$ AMEX firms enter CRSP in 1962 and NASDAQ firms in 1972. Since NASDAQ firms traded over-the-counter before 1972 and AMEX's predecessor (the New York Curb Exchange) dates back to at least 1908, we adjust the entering capital in 1962 and 1972 by re-assigning most of it to an approximation of the "true" entry years. We do this by using various issues of Standard and Poor's Stock Reports and Stock Market Encyclopedia to obtain incorporation years for 117 of the 274 surviving NASDAQ firms that entered CRSP in 1972 and for 907 of the 5,213 firms that entered NASDAQ after 1972. We then use the sample distribution of differences between incorporation and listing years of the post-1972 entrants to assign the 1972 firms into proper "IPO" years. See Jovanovic and Rousseau (2001a) for a more detailed description of these adjustments.

${ }^{3}$ The cumulative investment series is private domestic investment from Kendrick (1961), table A-IIa for 1885-1953, joined with estimates for more recent years from the National Income and Product Accounts. We construct the series by inflating the annual investment series to represent 1998 dollars, summing across the years, and then assigning each year its percentage of 1998 value.
} 


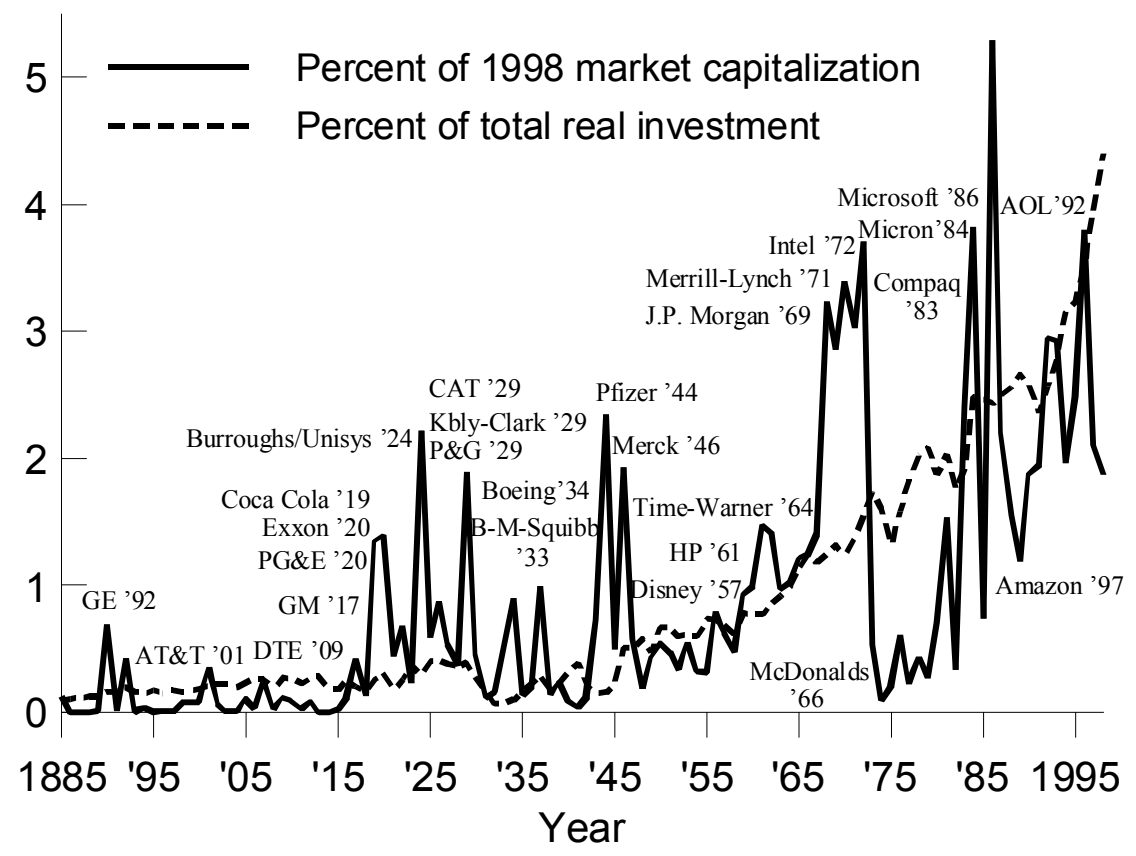

Figure 1: Annual U.S. gross investment and the 1998 value of all listed firms by year of listing.

share of all '20s investment, (b) delivered a higher return per unit of investment or $(c)$ invested more than other firms in subsequent decades. The state of technology prevailing at the firm's birth affects that firm for a long time, sort of like the weather affects a vintage of wine; some vintages of wine are better than others, and the same seems to be true of firms. In other words, the quality of the entering firms is better in some periods than in others. Jovanovic and Rousseau's (2001a) model attributes the differences between the solid and dashed lines in Figure 1 to factors 1(a), and 1(b) alone - a quality explanation as one would naturally use with vintage wines. Implicitly, we appeal to the market power that a firm derives from the patents that it may own on its inventions and products. These innovations create "organization capital," which can be defined as the intangible features of a firm that make it more valuable than the simple sum of its assets. We believe that organization capital depreciates more slowly than physical capital because it can stay intact in the face of equipment replacement and employee turnover. New members of a firm acquire it from the older ones and the firm's organization capital thus survives. This intangible part of the firm's capital stock is the main reason why, in Figure 1, we see lasting effects of a firm's vintage on market value.

2. Mergers and spin-offs: The dashed line is aggregate investment, not the invest- 
ment of entrants (on which we do not have data). The entrants of the 20's were, perhaps, not new firms embodying new investment but, rather, existing firms that split or that merged with other firms and re-listed under new names, or privately held firms that went public in the '20s. We accordingly adjust Figure 1 for mergers to the extent that is possible with available data. ${ }^{4}$ Some mergers may reflect a decision by incumbents to redirect investment and re-deploy old capital to new uses. Such mergers arise because of technological change. Others may arise because of changes in antitrust law or its interpretation. Either way, some firms engage in mergers as a precursor to exchange listing, and this means that a new listing may be a pre-'20s entity disguised as a member of the '20s cohort. $^{5}$

3. Financing. The entrants of the '20s may have financed a higher-than-average share of their own investment by issuing shares, or they later (e.g., in the 1990's) bought back more of their debt or retained more earnings than other firms did. We can be reasonably sure, however, that today's successful firms did not acquire their currently-high stock-market valuations by converting their debt into equity. Figure 2 presents the combined market value of all firms in our

\footnotetext{
${ }^{4}$ The merger adjustment uses several sources. CRSP itself identifies 7,455 firms that exited the database by merger between 1926 and 1998, but links only 3,488 (46.8\%) of them to acquirers. Our examination of the 2000 Edition of Financial Information Inc.'s Directory of Obsolete Securities and every issue of Predicasts Inc.'s FESS Index of Corporate Change between 1969 and 1989 uncovered the acquirers for 3,646 (91.9\%) of these unlinked mergers, 1803 of which turned out to be CRSP firms. We also recorded all mergers from 1895 to 1930 in the manufacturing and mining sectors from the original worksheets underlying Nelson (1959) and collected information on mergers from 1885 to 1894 from the financial news section of weekly issues of the Commercial and Financial Chronicle. We then recursively traced backward the merger history of every 1998 CRSP survivor and its targets, apportioning the 1998 capital of the survivor to its own entry year and those of its merger partners using the share of combined market value attributable to each in the year immediately preceding the merger. The process of adjusting Figure 1 ended up involving 5,422 mergers.

${ }^{5}$ An analysis of mergers in the manufacturing and mining sectors in the '20s, however, suggests that capital brought into the market by entering firms shortly after a merger cannot account for very much of the entry in Figure 1. We reached this conclusion after examining all 2,701 mergers recorded for the '20s in the worksheets underlying Nelson (1959). Many mergers involved a single acquirer procuring multiple targets in the course of consolidation. We included the value of acquirers that entered the NYSE anytime in the next two years and remained listed in 1998 as part of value brought into the market via a '20s merger. We also checked delisted '20s acquirers to determine if they were predecessors (through a later acquisition or sequence of acquisitions) to a CRSP firm that was listed in 1998, and treated these mergers similarly. The percentages obtained by dividing the 1998 value of all entering post-merger capital by the 1998 capital implied by the solid line in Figure 1 for each year of the 1920's were 6.81 in 1920, 0.53 in 1921, 0.67 in 1922, 1.77 in 1923, 0.02 in 1924, 1.91 in 1925, 7.32 in 1926, 2.07 in 1927, 5.95 in 1928, 0.41 in 1929, and 1.59 in 1930. Since the method attributes all entering capital to the merger targets even though much of it probably resided with the acquiring firm prior to merger and some may reflect post-merger appreciation of market value, these figures are likely to overstate the actual amounts of entering capital associated with mergers. This was necessary because we have no record of the value of unlisted targets prior to merger and entry of the acquirers.
} 
sample as a share of GDP, as well as aggregate debt of U.S. businesses, defined here as the sum of the market value of corporate bonds and commercial and industrial bank loans. ${ }^{6}$ The shaded areas denote periods of economic contraction as defined by the National Bureau of Economic Research. The Figure indicates that around 1915, equities started to grow faster than debt - indeed, while stocks rose ten times faster than GDP, debt starts and ends the period at about 50 percent of GDP. Moreover, none of the four large humps in the value of stocks were associated with a flight out of debt - in fact the two series are highly positively- correlated at those frequencies, with a correlation coefficient of 0.85. Even though we know that the fraction of capital investment financed by stocks has not been constant, there is no evidence in Figure 2 to suggest a substitution of debt finance into equity. Thus, such shifts cannot be used to explain the departures of the solid line from the dashed line in Figure 1 - not generally, and not for the 20's in particular.

4. Bubbles: The '20s cohort may be overvalued, as may be the high tech stocks of the 1990's, while other vintages may be undervalued. Note, however, that Figure 1 is a cross-section plot of values in 1998 and not a time-series plot. As we shall see, the cross-vintage differences in value have been highly persistent over time, and this is inconsistent with the crashes of stock-market prices, such as Japan's stock market crash in 1990 and NASDAQ's post-2000 crash, that are often pointed to by adherents of the bubbles view.

5. Market power, monitoring: The '20s cohort may be in markets that are less

\footnotetext{
${ }^{6}$ We obtain business debt for 1945-2000 from the Federal Reserve Board's Flow of Funds Accounts as the sum of corporate bonds and bank loans (Table L.4 lines 5 and 6 ). We join these totals with those for the book value of outstanding corporate bonds from Hickman (1952) for 1885-1944, splicing his series for railroad bonds (1885-1899) with his series for all corporate bonds which begins in 1900. Commercial and industrial bank loans for 1939-1944 are from the Federal Reserve Board's All Bank Statistics, and are joined with all non real-estate, non-collateral loans for 1896-1938. We then join this result with total loans from the U.S. Census Bureau's (1975) Historical Statistics of the United States (series X582). The figures from All Bank Statistics and Historical Statistics are for dates closest to June 30, and so we average them across years to be consistent with the calendar-year basis of the Flow of Funds.

We convert the book valuations of the above debt into market values using the annual average of monthly yields on AAA-rated corporate bonds from Moody's Investment Service for 1919-2000 and Hickman's "high grade" bond yields, which line up with Moody's precisely, for 1900-1918. Yields on "high-grade industrial bonds" from Friedman and Schwartz (1982) table 2.8 are used for 1885-1899.

To determine the market value, we let $r_{t}$ be the bond interest rate and then compute

$$
r_{t}^{*}=\frac{1}{\sum_{i=1885}^{t}(1-\delta)^{t-i}} \sum_{i=1885}^{t}(1-\delta)^{t-i} r_{t-i} .
$$

Therefore $r_{t}^{*}$ is a weighted average of past interest rates. We then choose a $\delta$ of $10 \%$ to approximate the growth of new debt plus retirements of old debt. Finally, we multiply the book value of outstanding debt by the ratio $\frac{r_{t}^{*}}{r_{t}}$ to obtain its market value.
} 


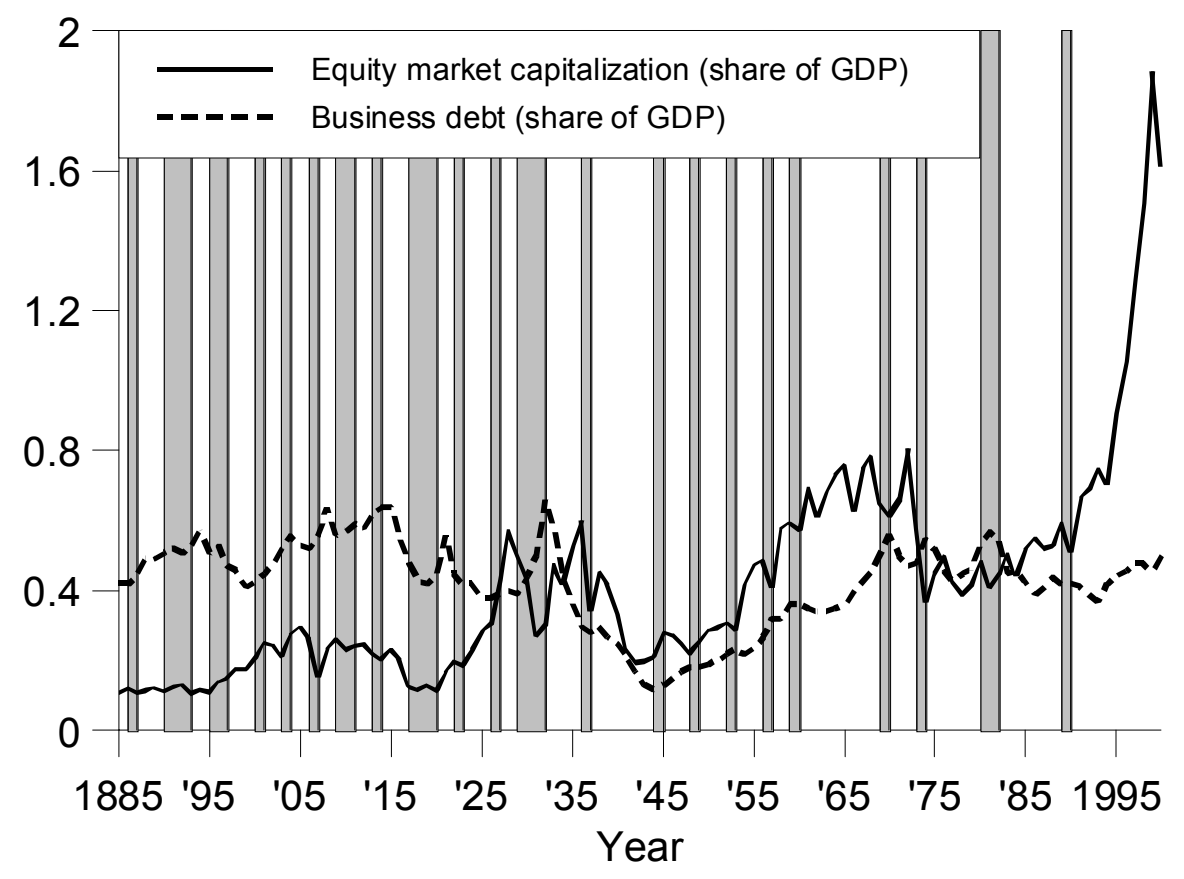

Figure 2: Aggregate business debt in the United States and the market capitalization of common stocks listed on the NYSE 1885-2000, AMEX 1962-2000, and NASDAQ 1972-2000.

competitive or in activities for which shareholders can monitor management more easily. For example, the very success of the internet technology has lowered markups and increased the pace with which internet-based applications reach obsolescence. The first effect is there for the old and new economy alike. But the second is restricted for the most part to the high-tech sector. Such an effect is likely to have become more serious recently and may be partially responsible for the relative decline of technology stocks.

\section{Stability of vintages over time}

The question of whether high price-earnings ratios signal that there is a bubble or an unsustainable component to stock prices naturally leads to the question of what happened in the past to firms or vintages of firms that appeared to be overvalued. The two episodes that usually come to mind are the crash of 1929 in the United States and the crash of 1990 in Japan. We do not analyze Japan here, but for the United States, while the market as a whole was probably overvalued in early October of 1929, the firms that entered the market during the '20s were not overvalued. 


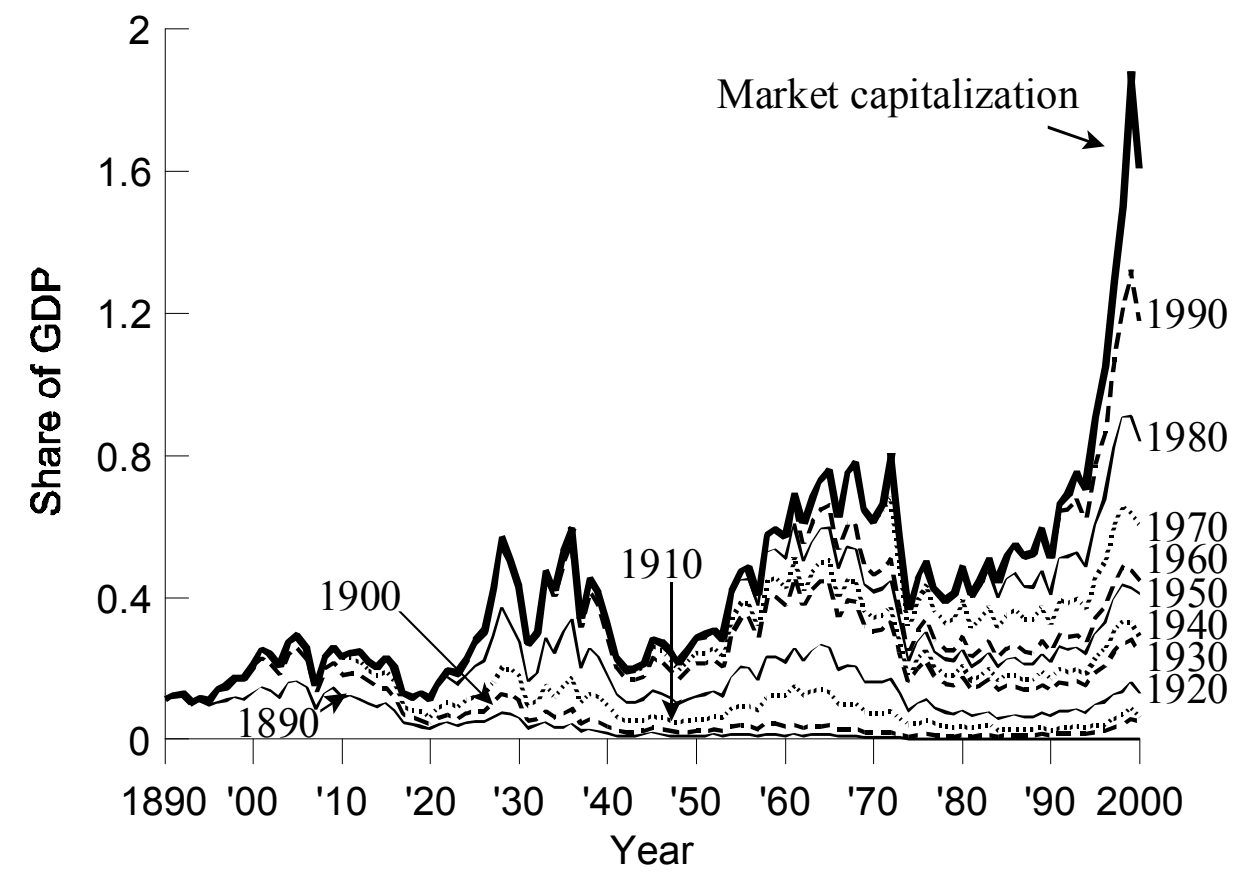

Figure 3: Shares of market capital retained by ten-year incumbent cohorts (ratio to GDP)

The stock-market values of various vintages of firms have been highly stable over time. That is, if a firm today is overvalued relative to its fundamentals, it has always been overvalued, and that seems highly improbable. This can be seen in Figure 3, which shows the evolution of market share for stock market incumbents at ten-year intervals. It is not the retention of ordering by vintage that is interesting, since this arises by definition due to the figure's focus on incumbents rather than vintages, but rather the stability of the relative spacing between lines that reflects a stability in the values of vintages over time. The thickest decadal strip is for the firms of the 1920s. If the market had overvalued these firms in 1929, the strip would have gotten much thinner when divided by output, and this evidently did not happen. Figure 4, which traces the value of each vintage as a share of total stock market capitalization, shows even more clearly that after the 1929 crash and into the onset of the Great Depression, it was the pre-1910 vintages of firms that permanently lost market share.

The stability of the vintages' values shown in Figures 3 and 4 suggests that organization capital depreciates slowly - so slowly that the imprints made by firms of various entering cohorts seem to persist despite the entry of new firms and the technologies that they carry into the stock market. Organization capital is therefore not something that is necessarily embodied in a particular technology or type of equipment, but is rather a firm attribute that remains intact as other inputs to the production 


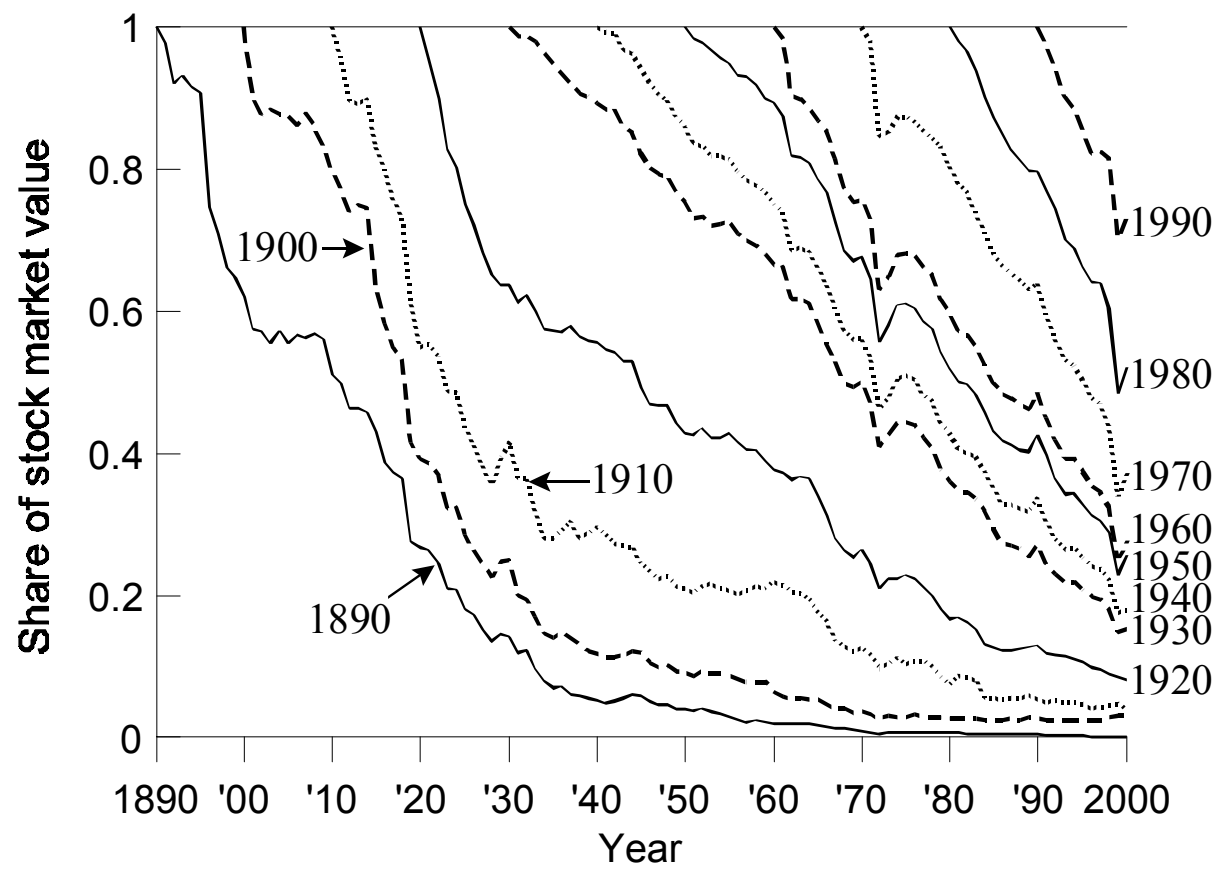

Figure 4: Shares of market capital retained by ten-year incumbent cohorts

process adjust. Perhaps firms that enter in the midst of technological change are ones in which innovation and entrepreneurship were not only encouraged but became embedded in the quality of management and the corporate culture generally. It is then easy to imagine that such firms would be able to adjust their inputs and product mixes with market conditions while maintaining their organization capital.

What does this cohort-specific stability imply for the IT-cohort? The recent decline of NASDAQ-listed firms has dramatically reduced the value that the 1990s entrants commanded in, say, 1999. The old economy firms did not lose as much value as did the new economy firms. In stark contrast, the crash of 1929 in the next several years affected the then-old vintages more than the then-new ones; in other words, the then-"old economy" firms suffered more in the long run. In spite of these differences between aftermath of the 1929 crash and that of NASDAQ, a lot of similarities between the IT and electrification revolutions remain, and it is these similarities that we turn to next.

\section{$5 \quad$ Lessons from the Electrification Era}

Paul David (1991) has claimed that the IT revolution looks a lot like the electricity revolution did a hundred years ago, and our data overall do support this claim. As we shall see below, in spite of the recent setbacks in the IT sector, experience so far 


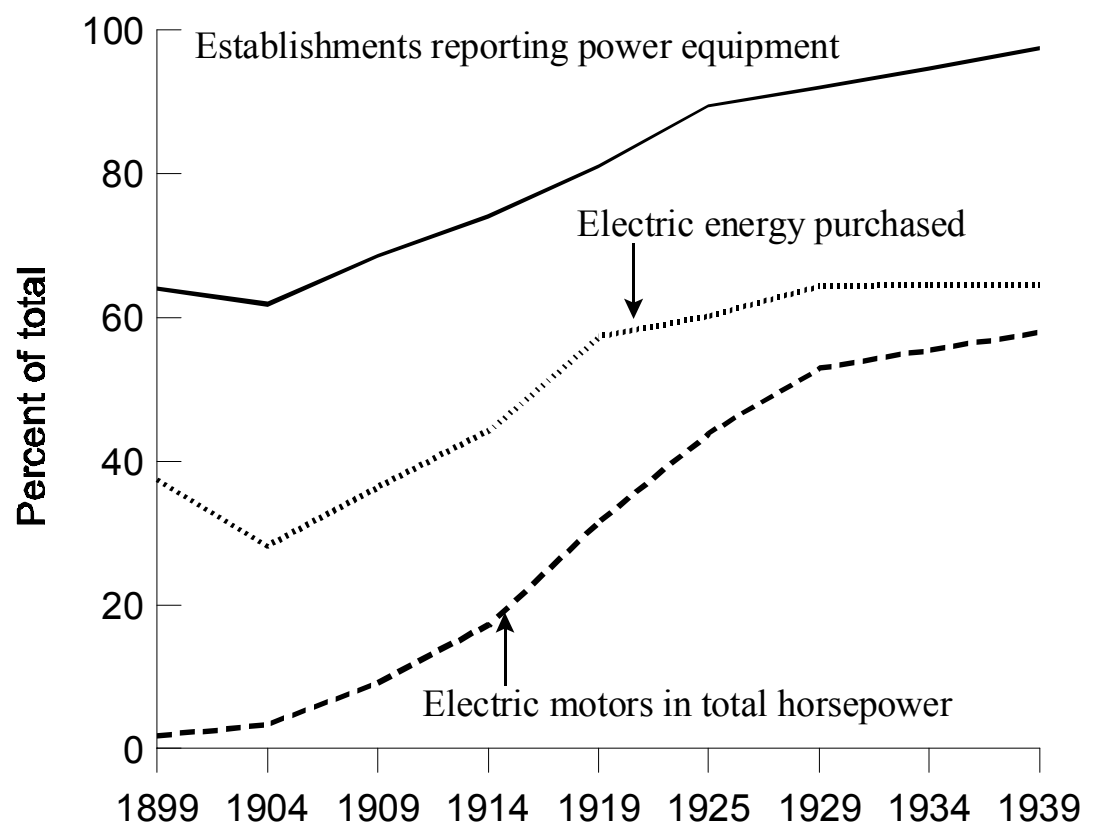

Figure 5: Electrification of U.S. factories, 1899-1939.

suggests that is not necessarily the first users of a technology that reap the greatest benefits. Can the same be said of electrification? Perhaps so. After all, Figure 1 shows that lasting value was not really created until the 20's. By then, if one considers the opening of the hydroelectric dam at Niagara Falls in 1894 as the start, electrification had already been on the scene for a quarter century. This suggests that the early entrants in the electrification era (with the exceptions of GE and AT\&T) were not, generally speaking, the firms that exploited the new technology most effectively.

It also appears that electrical technologies diffused more slowly than computers. Figure 5 shows that factory electrification started slowly at the turn of the 20th century and did not grow rapidly until after 1915, reaching its height only in the late 1920s. ${ }^{7}$ In Figure 6 we match up the spread of electricity with that of personal computer use by consumers. ${ }^{8}$ Indeed, electricity diffused more slowly than computers, but the parallels between the penetration of home lighting and personal computers are just as striking as the differences.

Why did electricity diffuse so slowly? In asking this question we should remember that 100 years ago, the financial playing field favored the large, established firm much more than it does today. The later rise of smaller firms may have been due partly to

\footnotetext{
${ }^{7}$ We obtain summary data on the diffusion of electricity and power equipment in factories from the U.S. Census Bureau's Census of Manufactures for 1939, table 1, p. 275.

${ }^{8}$ Data on the spread of electricity use by consumers are approximations derived from Historical Statistics (series S108 and S120). Statistics on computer ownership are from Gates (1999) p. 118, with the 2003 projection from Forrester Research, Inc.
} 


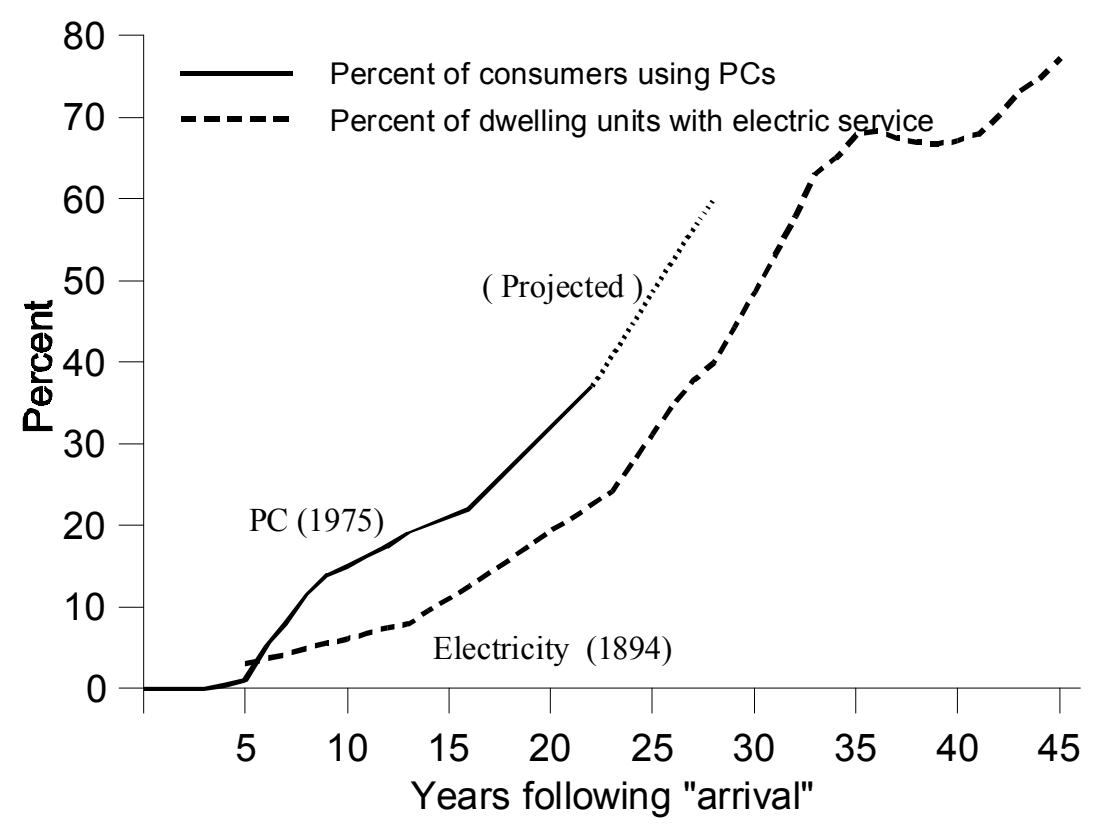

Figure 6: The diffusion of electricity and personal computers among U.S. consumers.

changes in the law (such as the Sherman antitrust act of 1890 and the transparency forced on the market by the Securities' Acts of 1933) but it probably stemmed much more from a gradual but profound change in both technology and in the growth of expertise with which business is financed.

The capital market was not nearly as deep in the 1920's as it is today - some 50 percent of Americans own stock today, whereas only three or four percent owned stocks in the 1920's, and even less in the 1890's. Moreover, Wall Street's financial expertise was concentrated in a few large banks. The market was thus less well prepared to float shares of smaller firms, and the big bankers of the era as a rule shied away from new issues by unknown companies. Navin and Sears (1955), for example, discuss the formation of the industrial market in New York around the turn of the century, and find that only large firms and combines were usually able to capture the attention of the nation's early financiers. Nelson (1959) notes that only 19.6 percent of all consolidations during the first merger wave traded on the NYSE sometime in the next three years. In addition, between 1897 and 1907 the total value of cash issues to the general public (\$392 million) was only 11.6 percent of the value of securities that were exchanged for the assets and securities of other companies. It appears, then, that the small company had a harder time a century ago. As we shall see, however, although the financial market was probably less efficient a hundred years ago, it did not prevent young firms from listing and, so, it cannot have been the main reason why electrification did not spread faster than it did. 
Other factors, present a century ago but largely absent today, played a role in slowing down the spread of electricity. First, technological information did not spread as fast as it does today. An indirect indicator is the spread of product innovations and the growth in the number of their producers. Agarwal and Gort (1999) give evidence that a new product diffuses through the economy much faster today than it would have 100 years ago, leading us to expect a more protracted playing out of events in the electricity era. Second, the price of computing power is falling at a much faster rate than the price of electricity did. Gates (1999, p. 118) provides evidence, similar to that in Figure 6, that computers are penetrating the household sector faster than other consumer durables did early in the 20th century. Third, the adoption of electricity by factories seems to have gone through a peculiar twostage adoption process: Located to a large extent in New England factory towns, textile firms around the turn of the century readily adapted the new technology by using an electric motor rather than steam to drive the shafts which powered looms, spinning machines and other equipment (see Devine 1983). This early and only partial adoption of electricity was further delayed by lags in the distribution of the new power - lags that made it more costly to electrify a new industrial plant fully. It is only after 1915, when secondary motors begin to receive widespread usage, that industrial listings take off on the NYSE and outperform railroads. This is broadly similar to the recent and more compressed pattern of decline, merger, and gradual acceleration in IT-intensive industries since 1985, except that the IT-intensive industries are the service industries, not manufacturing.

\section{Age of incumbents}

As Schumpeter emphasized, technological change destroys old technologies and old businesses. New technologies and products are usually brought in by young companies and this means that - with some delay - when a new technology comes to market, an economy's leading firms tend to get younger. One signal, then, that a new technology has come on the scene is a drop in the average age of the leading firms.

Figure 7 shows the average age of the largest firms whose market value sums to 5 percent of GDP for each year since 1885 using both years since incorporation and years since exchange listing as measures of age. ${ }^{9}$ Some of the more prominent entries and exits (denoted by an "X") to this elite group are also labelled. The leading firms were getting older over the first 30 yeas of our sample period and were largely railroads, but manufacturing firms began to list rapidly on the NYSE after 1914 as the use of electrified plants became widespread. The Pullman Company, which manufactured railroad cars and equipment until the $1980 \mathrm{~s}$, is a case in point, entering the 5 percent

\footnotetext{
${ }^{9}$ Listing years are those for which firms enter our extended CRSP database. Incorporation dates are from Moody's Industrial Manual (1920, 1928, 1955, 1980), Standard and Poor's Stock Market Encyclopedia (1981, 1988, 2000), and various editions of Standard and Poor's Stock Reports.
} 


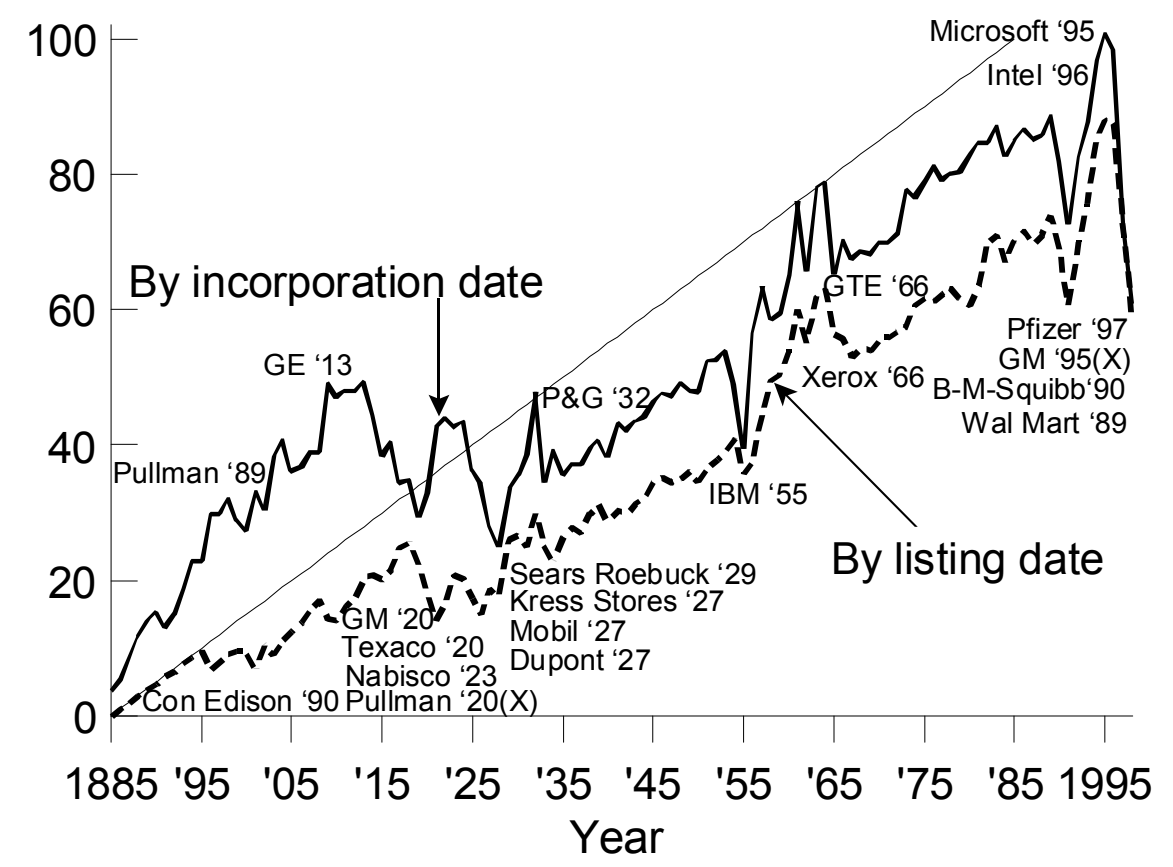

Figure 7: Average age of the largest firms whose market values sum to 5 pecent of GDP in each year.

group in 1889 and remaining there until it was replaced by GM in 1920. In fact, the average age of the largest firms, based upon year of incorporation, dropped from nearly 50 years to just under 30 years between 1914 and 1921 .

The two decades that followed the Great Depression saw relatively few firms enter the stock market. Accordingly, the largest firms, which in the vast majority of cases were able to ride out the Depression, remained large. This is clear from the $45^{\circ}$ slope of the average age lines in Figure 7 between 1934 and 1954. The leaders have been getting younger in the 1990s, and their average ages now lie well below the $45^{\circ}$ line. We attribute this shake-out to the computer and to the internet.

A comparison of Figure 7 with Figure 1 reveals another interesting fact - over the past 115 years, times when lasting value was created correspond to periods when the market leaders were replaced by younger firms. This is particularly true of the '20s and the 1990's.

We concluded earlier that the 1920's entrants held up pretty well in the long run. Let us now consider the 1990s and the IT industry more closely. Figure 8 shows the shares of total market value that can be attributed to early IT entrants that turned out to be the losers, and the later entrants that turned out to be the winners. The losers include IBM, Burroughs/Unisys, Honeywell, NCR, and Sperry-Rand, DEC, Data General, Prime Computer, Scientific Data Systems, and Computer Associates 


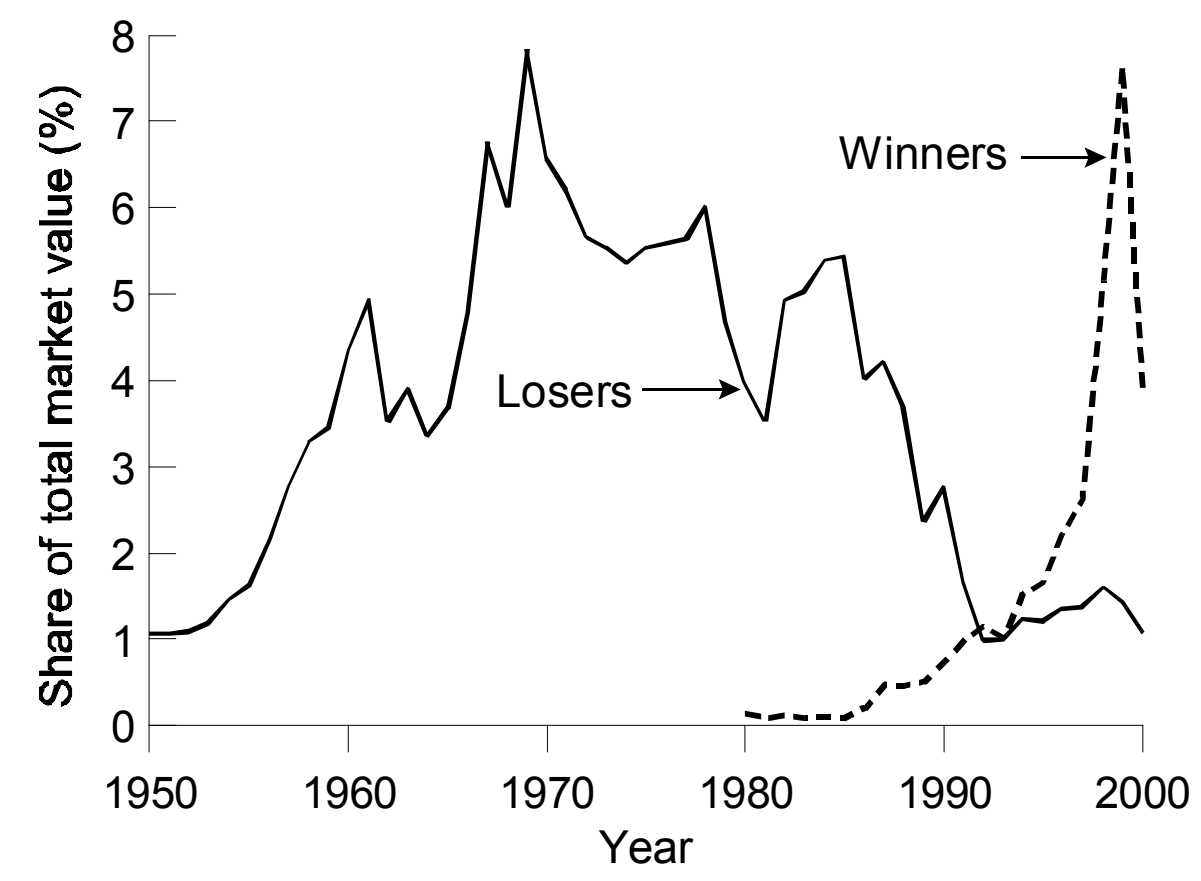

Figure 8: Winners and losers in the IT industry.

- all early providers of mainframe or minicomputer products and services. The winners include Apple, Compaq, Dell, Gateway, Informix, Microsoft, Novell, Oracle, Peoplesoft, AOL, Infoseek, Lycos, Netscape, and Yahoo - later providers of personal computers, software, and internet services.

The early IT leaders produced and supported hardware that was expensive to maintain and to use. Software for these mainframes and minicomputers were for the most part homegrown, either by a firm's internal programmers or perhaps with the assistance of the hardware provider. Migration of applications from older to newer computers was slow and prone to error as programmers demonstrated considerable job mobility and documentation for homegrown applications could often be sparse. Many firms became "locked-in" to their data processing systems, and were slow to change. The early leaders were thus, in spite of the growing use of personal computers in the mid-1980s, able to continue to service a variety of customers and to maintain their market shares.

But firms did finally either change or disband. And when they did, a second round of innovations, more sweeping than the first, transformed the U.S. marketplace. Software became more standardized, more easily customized, and easier to use. Analysts had already solved most everyday business problems (i.e., accounts payable, ordering, project planning) with applications during the first IT wave, and this combined expertise led to new, generic software that could suit most businesses 


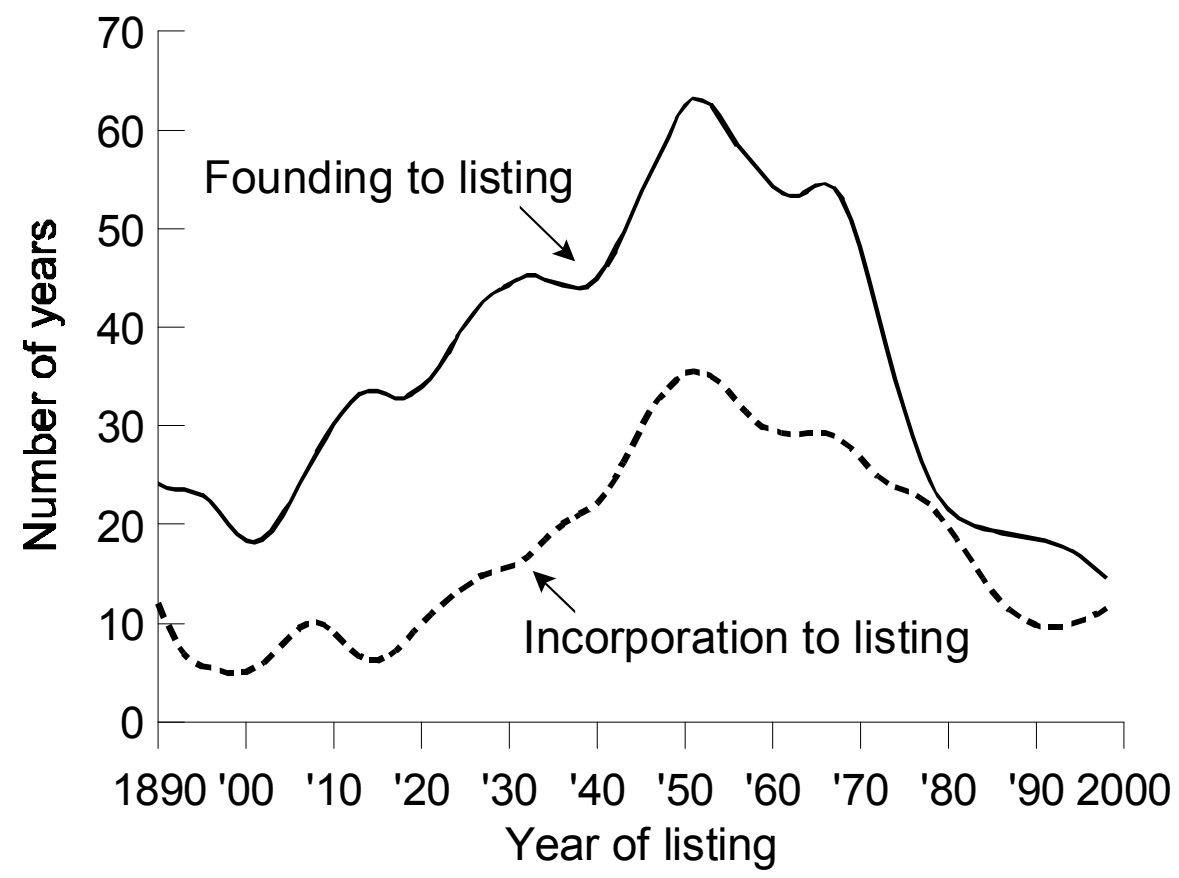

Figure 9: Waiting times to exchange listing.

directly off the shelf. The price of computers fell rapidly, as did the demand for specialized programmers within the business firm. The internet provided new ways to advertise and sell products. Firms that were able to adjust their organizations to the second wave of IT began to phase out old systems and hardware. Others, for which adjustment represented too large a burden, exited. New firms, without the weight of older systems and workplace designs built around them, were able to adopt the cheaper and better technology quickly. The older IT providers, with their organization capital built around customer dependence and reliable service, began to lose ground.

\section{$7 \quad$ Age of entrants}

When considering Table 1, we noted that some of today's larger firms were brought to market quickly both recently and in the early part of the 20th century, while firms that listed in the middle of the century were considerably older. Is this too a general characteristic of U.S. firms? Apparently so. Figure 9 shows that companies that first listed at the close of the 19th century were as young as the companies that are entering the NYSE, AMEX and NASDAQ today. The figure shows average waiting 
times from founding and incorporation to exchange listing. ${ }^{10}$ While it is true that transactions costs were lower at the beginning and end of the 20th century than they were in the middle (see Jones 2001), their absolute magnitude and variation over time have been too small to account for the decisions of so many firms in the middle part of the century to delay their entry to the stock market.

The finance expert would attribute a rapid life cycle from founding to IPO as a result of increasingly sophisticated financial markets, but the evidence in the data does not support such a view. Firms took as long to list at the turn of the 20th century as they are taking today, and waiting times were much longer in the 1940-60 period. A part of this may be the result of the Securities Act of 1933 that diverted some new start-ups from the NYSE to the over-the-counter (OTC) market where they could escape the more stringent listing requirements. This can explain only a part of the increase, however, because the rise in age of listing firms is evident well before the 1929 crash and the Act of 1933 .

The debate continues on how much real effects the Act of 1933 did have - see Simon (1989) - but it seems safe to conclude that neither legal changes nor financial regression can explain the rise in listing ages. The natural candidate therefore seems to be the nature of the technologies that came along during the three different epochs - early, middle, and late century. As noted earlier, chemical and pharmaceutical firms were the important entrants of the 1940-60 period, and most had existed for many decades prior to listing. Is it possible that the need to be flexible is something especially true of these industry? In other words, does the mid-century listing pattern suggest that it is not just the quality of the firms but the identity of the sectors that determine how fast an idea can come to market?

\section{Direct technological indicators}

One indicator of innovative activity within a firm is the number of patents that it secures. Not all ideas that define a firm are patented early in its life, but the level of patenting activity in an economy is probably related to the number of new ideas being generated there. It also reflects the entrepreneurial climate, since patents are often used to protect property rights to products that have emerged from the R\&D process, whether such R\&D is recognized on a company's books or not. Moreover, it is the property rights of the firm that defines what the firm is about, and what its organization capital will be built around.

Figure 10 shows the number of patents that have been issued annually in the U.S. economy since $1885 .{ }^{11}$ This figure has a U-shape, suggesting that the pace of

\footnotetext{
${ }^{10}$ We applied the Hodrick-Prescott filter to all three series before plotting them. The data set that we used to compute waiting times is described in Jovanovic and Rousseau (2001b).

${ }^{11}$ Data on the number of patents issued are from the U.S. Patent and Trademark Office for 19632000 and from Historical Statistics (pp. 957-958) for earlier years.
} 


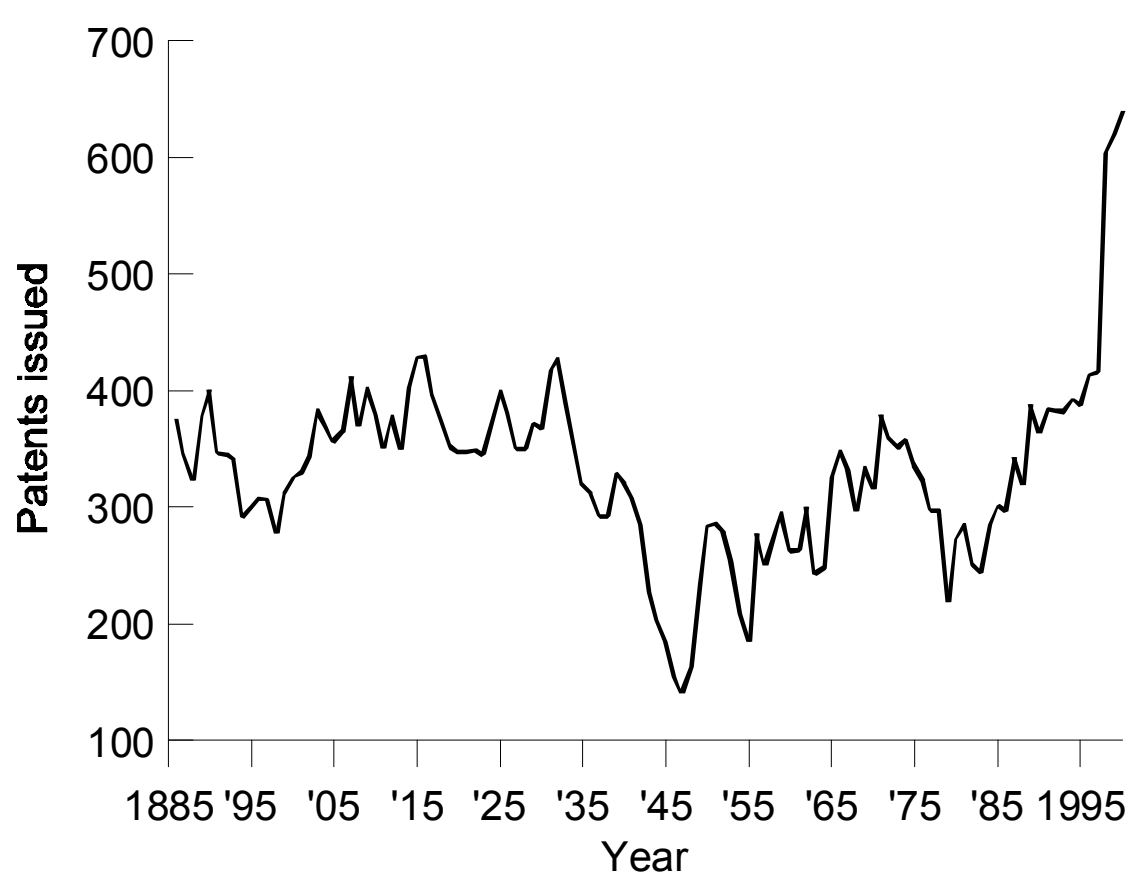

Figure 10: Patents per million in the population.

innovation was greater during times of rapid technological change, such as the 1920s and the post 1985 period, while it was slower during the middle of the century, which was the age of the technology-refining incumbent. This graph, though somewhat smoother than the plot of market value by vintage in Figure 1, has a similar pattern after detrending. The rise over the past four years has been remarkable, and Lerner and Kortum (1998) argue that technological change has led to this surge.

Changes in patent legislation will affect the number of filings and issues, and could account for some of the fluctuations in Figure 10. Nevertheless, changes in patent laws themselves often arise due to technological change. For example, legislators may act to encourage innovation and competition by lowering fees and extending patent lengths when a new technology is perceived as having the potential to transform industry even though individuals entrepreneurs are not yet ready to bear the start-up costs. They might raise fees and shorten patent lengths later in the technological cycle to offer protection to firms that did bear the costs of bringing in a new technology. Either way, patent laws are more likely to change during times of technological transformation.

When examining patent laws in a single country such as the U.S., it is often unclear whether changes are a result of technology or some country-specific factor, such as a shift in political leadership. Global patterns, however, can be more plausibly linked to technological factors. Figure 11 presents cross-country averages of changes in patent legislation at ten-year intervals from 1850-1990 for as many as 60 countries 


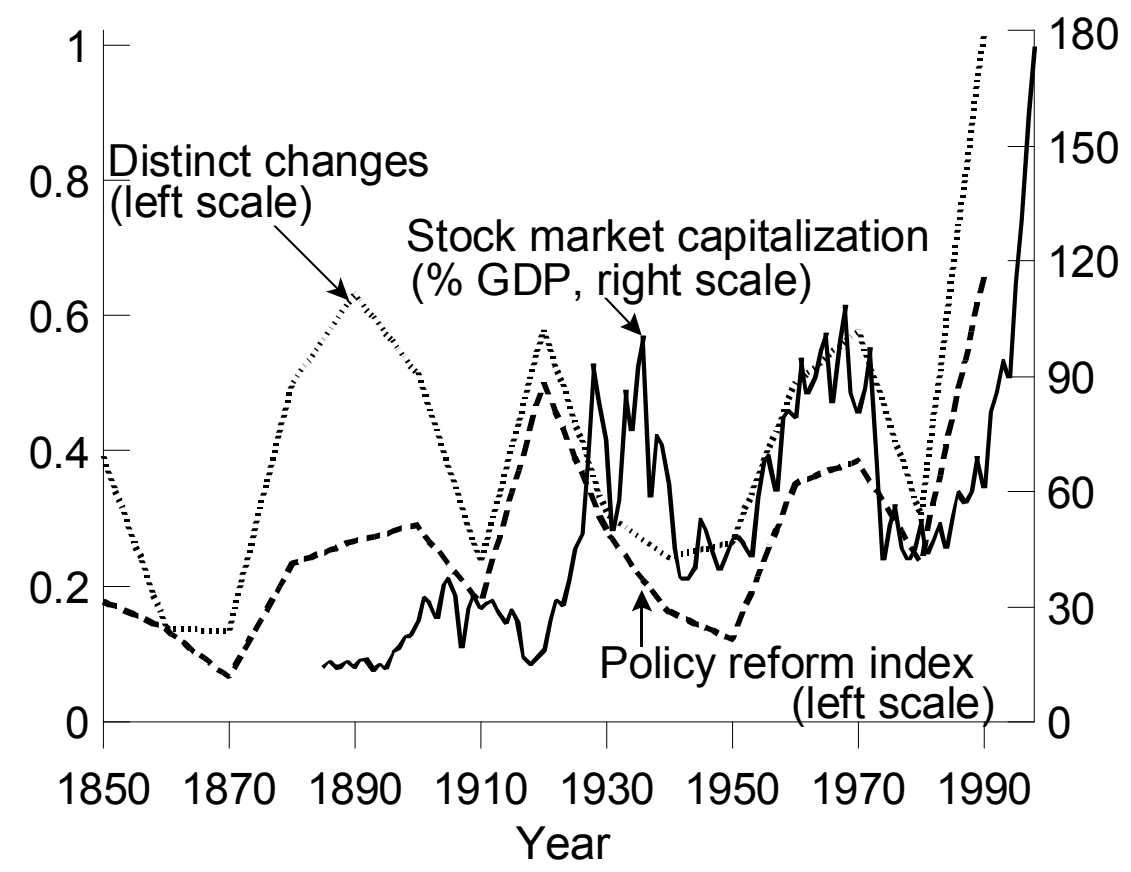

Figure 11: Worldwide changes in patent laws and U.S. stock market size.

that were compiled by Josh Lerner (2001), and contrasts these with the size of the U.S. stock market with respect the GDP. ${ }^{12}$ In the figure, a country with at least one change in patent law in a given year counts once in the "policy reform index," while multiple changes in a single year are all counted in the measure of "distinct policy changes." Lerner distinguishes discretionary changes in government stance towards patenting from changes associated with the establishment of a new nation, a revolution or coup, or temporary measures during times of war, and excludes these more special cases from his counts of policy changes. Both indexes are normalized by the number of active countries in the sample at the beginning of the decade to adjust for wide disparities in the country coverage over time.

The close relationship between patent policy changes and the performance of the U.S. stock market is apparent in Figure 11, with periods of policy reform often preceding increases in the total value of the stock market. If Lerner's indexes are

\footnotetext{
${ }^{12}$ Lerner determines the number of changes in patent policy in a given year by examining patent office documents and legal monographs that involved patent policy. His sample consists of the 60 countries with the highest total gross domestic product in 1997. He counts patent fee changes as policy reforms only when they rise by more than 100 percent or fall by more than 50 percent in an attempt to eliminate changes in fees with little real effect that were brought about by periods of moderate to high inflation. See Lerner (2001) for complete documentation of this new and informative dataset.
} 


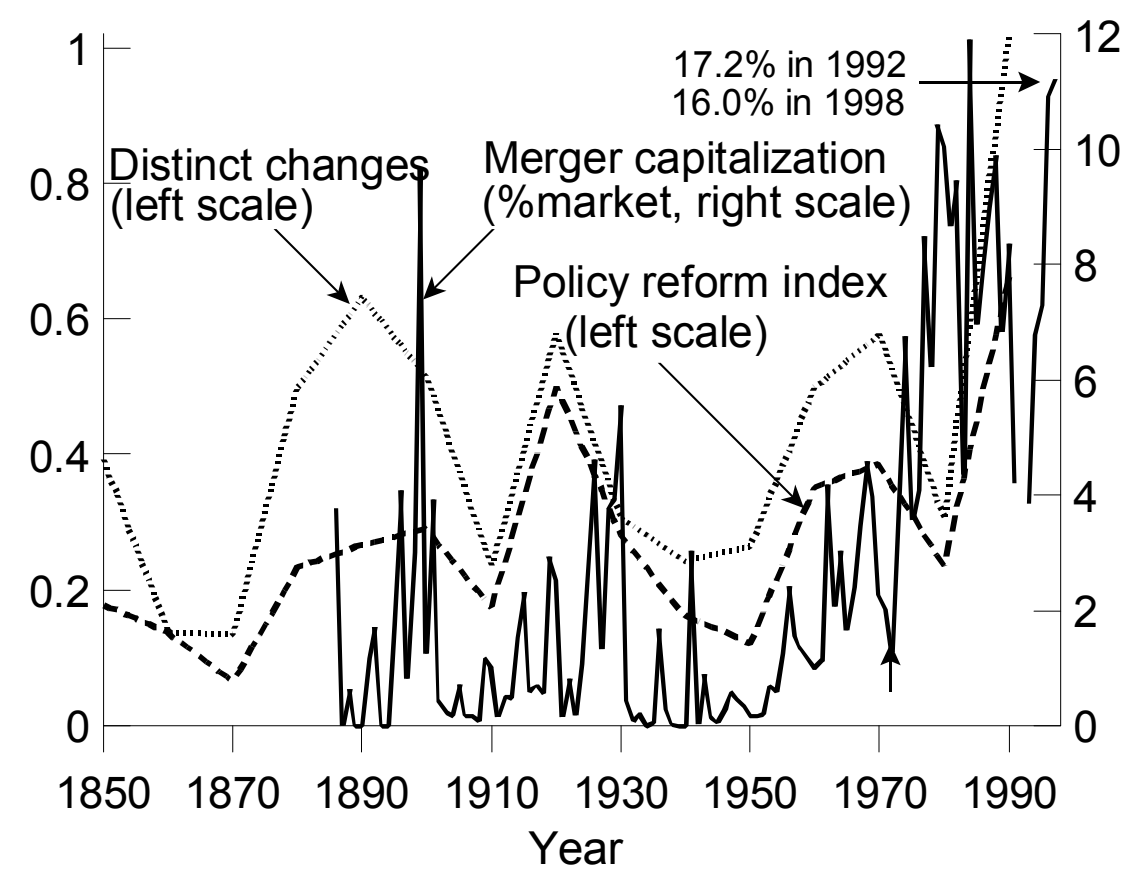

Figure 12: Worldwide changes in patent laws and the ratio of merger capitalization to stock market size in the United States.

reasonable proxies for the state of technology, and we believe that they are, the lowfrequency correlation between the series suggests that the stock market recognizes new technologies quickly and values them accordingly. The lags that we observe in the '20s between patent law changes and market value may just reflect changes in the ease with which new firms can list, as today's NASDAQ now stands ready to absorb innovative firms.

In Figure 12, we contrast Lerner's cross-country measures with the ratio of merger capital to stock market capitalization in the United States from 1885 to $1998 .{ }^{13}$ Since we normalize by stock market size in the figure, we include only mergers among firms that are both listed in our extended CRSP database. Despite this limitation, the five merger waves of the past century all stand out, including that of the turn of the 20th century, the late 1920s, the late 1960s, the mid-1980s, and the current wave which began around 1993. Like the size of the market generally, increases in merger activity also occur at times when changes in international patent laws occur frequently.

\footnotetext{
${ }^{13}$ We include in Figure 12 the market values of firms in our extended CRSP database, both acquirers and targets, at the end of the year before the merger. This restricts the merger series to include NYSE-listed firms from 1885, with the additions of AMEX-listed firms from 1962 and Nasdaq firms from 1971. We apply the corrections to the CRSP files described in footnote 4 to reflect all merger activity prior to computing the totals.
} 
It is natural to think that mergers should be associated with technology. Gort (1969), for example, argued that technological change would raise the dispersion in how much potential alternative owners would value a particular asset. After the technological shock, the highest valuation of a firm's assets may shift to someone outside who then may try to acquire that firm. A shock that was large enough could thus set off a merger wave. The argument extends to any shock that rearranges comparative managing advantage. Some firms will react to the shock better than others. A firm that cannot adapt will become a takeover target, or it may try to survive by acquiring some other firm that does have the expertise needed to cope in the new environment. The larger and wider ranging the shock, the larger the resulting merger wave. Jovanovic and Rousseau (2000c) formalize some of these themes in a model of mergers as a reallocative mechanism that operates rapidly during times of technological change. In the model, new technologies are carried in by entrants who are more efficient than incumbent firms. These entrants combine with existing firms who can adjust to the new technology to acquire the less efficient and older firms. This occurs rather than exit because mergers offer a means to acquire capital with at least part of its organizational component intact. As a merger wave begins, the demand for the capital of less efficient incumbents rises, causing their values to rise on the merger market, and encouraging these firms to seek to be acquired rather than liquidated.

Figure 12 thus suggests that mergers are caused by factors that transcend countryspecific legal changes. It also appears that merger waves have been quite synchronous in the few countries where we have enough data to tell. McGowan's (1971) study of the U.S., Canada, the U.K. and France showed strong intercountry similarities in the industries that experienced high merger activity. At the turn of the 20th century and in the 1960's both Britain and the U.S. experienced bursts of merger activity (Nelson 1959), and in the '60s so did Sweden, Canada, the Netherlands, and Japan (Singh 1975, Matsusaka 1996). Britain and the United States both had merger waves in the 1980's (Town 1992), and the merger wave of the 1990's affected many advanced economies.

\section{What next? The second democratization of knowl- edge}

One difference, not yet discussed, between electricity and IT is that, while both enable more outputs to be produced with the same inputs, IT is probably much more valuable in the process of invention. Computers are essential in the process of gathering and disseminating the relevant information, in designing complex new products, of simulating the outcomes of experiments that are costly or time-consuming to perform, in coordinating research efforts of people that are often geographically separated, in market research and identifying consumer wants, and so on. We can, in other words, 
expect a faster stream of new products than we saw following the mass adoption of electricity. The surge in patenting during the last 6 years is an indication of that.

We also can expect further declines in the cost of computing power and in software, components that, in spite of their falling cost, are absorbing an ever increasing share of U.S. firms' investments. It is only a matter of time before world investment follows suit, and when it does, computers and software will be a real bargain even compared to today. Caselli and Coleman (2000, Table A.2) find that at the world level, the demand for computers has an income elasticity of about two. As the world's incomes rise, we can expect a vast number of new computers to be sold and, through a process of learning by doing, we can expect the costs of computing and information management and dissemination to decline even more dramatically. At least in the semiconductor industry, we know that learning is essentially global; Irwin and Klenow (1993) have found that learning spills over just as much between firms in different countries as between firms within a given country. They estimated that a doubling of cumulative output reduces costs by twenty percent.

The availability of cheap computers, better software, and faster internet access does not eliminate or even reduce the need for education in schools and colleges. The world will still need to provide the other complementary resources before it can take full advantage of information technology, and those other resources - mainly human capital - will not become cheaper as rapidly as computers will. Nevertheless, by eliminating many of the diffusion lags that stem from informational barriers, the computer and internet afford us the opportunity to do more effective and faster research closer to the knowledge frontier and to adopt frontier technologies much faster than before. The only comparable event surely was the invention of the printing press back in the fifteenth century that made scribal copying obsolete and gave access to knowledge to many more than the handful of aristocrats and monks that had enjoyed it previously. This was the first democratization of knowledge and it had profound effects on human development. As with the IT revolution, the scope of the printing press was limited by human capital - i.e., by the ability of people to read. But its scope quickly widened from Germany to England and elsewhere, and the printing press thereby made possible much of the scientific blueprints of the Industrial Revolution of the eighteenth century and beyond.

\section{References}

[1] Agarwal, R., and M. Gort. 1999. First mover advantage and the speed of competitive entry: 1887-1986. Working Paper. SUNY Buffalo.

[2] All-Bank Statistics, United States. 1959. Washington, DC: Board of Governors of the Federal Reserve System. 
[3] The Annalist: A Magazine of Finance, Commerce, and Economics. 1913-1925, various issues.

[4] Annual Guide to Stocks: Directory of Obsolete Securities. 2000. Jersey City, NJ: Financial Information Inc.

[5] Bradstreet's. 1885-1925, various issues.

[6] Caselli, F., and W. J. Coleman. Cross-country technology diffusion: The case of computers. American Economic Review 91(2): 328-35, Papers and Proceedings.

[7] The Commercial and Financial Chronicle. 1885-1925, various issues.

[8] Compustat database. New York: Standard and Poor's Corporation, 2000.

[9] Cowles, A., and Associates. 1939. Common Stock Price Indexes, Cowles Commission for Research in Economics Monograph No. 3. Second Edition. Bloomington, IN: Principia Press.

[10] CRSP Database. 2000. Chicago: University of Chicago Center for Research on Securities Prices.

[11] DEBB Million Dollar Directory. 2000. Bethlehem, PA: Dun and Bradstreet, Inc.

[12] David, P. 1991. Computer and dynamo: The modern productivity paradox in a not-too-distant mirror. In Technology and Productivity: The Challenge for Economic Policy. Paris: OECD.

[13] Devine, W. D. 1983. From shafts to wires: Historical perspective on electrification. Journal of Economic History 43 (2): 347-72.

[14] Flow of Funds Accounts, Fourth quarter 1999. Washington, DC: Board of Governors of the Federal Reserve System.

[15] Friedman, M., and A. J. Schwartz. 1982. Monetary Trends in the United States and the United Kingdom. Chicago: University of Chicago Press.

[16] Gates, B. 1999. Business @ the Speed of Thought. New York: Warner Books.

[17] Gort, M. 1969. An economic disturbance theory of mergers. Quarterly Journal of Economics, 94: 624-642.

[18] Griliches, Z. 1957. Hybrid corn: An exploration in the economics of technological change. Econometrica 25 (4): 501-22.

[19] Hickman, W. B. 1952. Trends and cycles in corporate bond financing. 1952. Occasional Paper No. 37. National Bureau of Economic Research. 
[20] Hoover's Online: The Business Network. 2000. Austin, TX: Hoover's, Inc.

[21] Irwin, D. A., and P. J. Klenow. 1994. Learning-by-doing spillovers in the semiconductor industry. Journal of Political Economy 102 (6): 1200-27.

[22] Jones, C. M. 2001. A century of stock market liquidity and trading costs. Working Paper. Columbia University.

[23] Jovanovic, B., and P. L. Rousseau. 2001a. Vintage organization capital. Working Paper No. 8166. National Bureau of Economic Research.

[24] Jovanovic, B., and P. L. Rousseau. 2001b. Why wait? A century of life before IPO. American Economic Review 91(2): 336-41, Papers and Proceedings.

[25] Jovanovic, B., and P. L. Rousseau. 2001c. Mergers as reallocation. Working Paper. University of Chicago and Vanderbilt University.

[26] Kelley, E. M. 1954. The Business Founding Date Directory. Scarsdale, NY: Morgan and Morgan.

[27] Kendrick, J. 1961. Productivity Trends in the United States. Princeton: Princeton University Press.

[28] Lerner, J. 2001. 150 years of patent protection. Working Paper. Harvard Business School.

[29] Lerner, J., and S. Kortum. 1998. Stronger protection or technological revolution: What is behind the recent surge in patenting? Carnegie-Rochester Conference Series on Public Policy 48: 247-304.

[30] Matsusaka, J. 1996. Did tough antitrust enforcement cause the diversification of American corporations? Journal of Financial and Quantitative Analysis 31: 283-94.

[31] McGowan, J. 1971. International comparisons of merger activity. Journal of Law and Economics 14 (1): 233-50.

[32] Moody's Industrial Manual. New York: Moody's Investors Service, 1920, 1928, $1955,1980$.

[33] Navin, T. R., and M. V. Sears. 1955. The rise of a market for industrial securities, 1887-1902. Business History Review 30 (2): 105-38.

[34] Nelson, R. L. 1959. Merger Movements in American Industry, 1895-1956. Princeton: Princeton University Press.

[35] The New York Times. 1897-1928, various issues. 
[36] Predicasts FESS Index of Corporate Change. Cleveland, OH: Predicasts Inc., 1969-1992.

[37] Simon, C. J. 1989. The effect of the 1933 Securities Act on investor information and the performance of new issues. American Economic Review 79 (3): 295-318.

[38] Singh, A. 1975. Take-overs, economic natural selection, and the theory of the firm: Evidence from the postwar United Kingdom experience. Economic Journal 85 (339): 497-515.

[39] Stock Market Encyclopedia. 1981, 1988, 2000. New York: Standard and Poor's Corporation.

[40] Stock Reports. New York: Standard and Poor's Corporation, various issues.

[41] Town, R. 1992. Merger waves and the structure of merger and acquisition time series. Journal of Applied Econometrics.

[42] U.S. Bureau of the Census, Department of Commerce. 1975. Historical Statistics of the United States, Colonial Times to 1970. Washington, DC: Government Printing Office.

[43] U.S. Bureau of the Census. 1940. Census of Manufactures 1939. Washington, DC: Government Printing Office. 